\title{
POLÍTICAS EDUCACIONAIS NO ESTADO DO PARANÁ E O ENSINO DA GEOGRAFIA NAS DÉCADAS DE 1990/2000'.
}

\section{Deuseles de Oliveira ${ }^{2}$}

Analisando-se a educação como um todo, constata-se que ela é legitimada na sociedade moderna por sua importância na formação de cidadãos participativos e conscientes de seu papel na melhoria da qualidade de vida da sociedade. Porém, para que essa educação ocorra, o Estado elabora, aprova e aplica as leis que regem o sistema educacional em todo o território brasileiro. Diante deste fato, analisar-se-a como os três últimos governadores do estado do Paraná produziram ou apenas aplicaram as leis educacionais federais. Entre as principais ações desses governos, destaca-se o Currículo Básico do Estado do Paraná lançado em 1990 no final do mandato de Álvaro Dias (1987-1990) e aplicado por seu sucessor, Roberto Requião (1991-1994). Nesse documento, pode-se destacar a forte ideologia teórica baseada no materialismo histórico e dialético de base marxista, a qual influenciou a proposta da maioria das áreas do conhecimento. $\mathrm{Na}$ segunda metade da década de 1990, assistiu-se a uma guinada na política educacional paranaense, pois o sucessor de Requião, Jaime Lerner (1995-2002), antecipou-se ao projeto neoliberal do futuro presidente Fernando Henrique Cardoso, e aplicou de forma efetiva ações neoliberais no setor educacional. Entre uma de suas medidas, destaca-se o abandono do ensino público, o que pode ter resultado no crescimento do sistema de ensino privado. Por fim, o atual governo do estado, Roberto Requião (2003-2006), faz um discurso populista e se diz defensor da escola pública e gratuita com qualidade. Diante disso, a presente proposta tem como objetivo principal analisar como os diferentes governadores conduziram as políticas educacionais no estado e que resultados tais ações trouxeram para o ensino como um todo e mais especificamente para o ensino de geografia.

PALAVRAS-CHAVES: geografia política; planos educacionais; currículo escolar.

\footnotetext{
${ }^{1}$ Orientador: Prof. Dr. Luis Lopes Diniz Filho

${ }^{2}$ Mestrando em Geografia (UFPR) - e-mail: deusgeo@superig.com.br
} 